\title{
Management, Leadership, and Governance in Secondary Education (Finland)
}

\author{
Varjo, Janne \\ Bloomsbury Publishing \\ 2019-11-19
}

Varjo , J 2019 , Management, Leadership, and Governance in Secondary Education (Finland) . in J Kauko, M T Tatto \& I Menter (eds), Bloomsbury Education and Childhood

Studies : Articles . Bloomsbury Publishing , London . https://doi.org/10.5040/9781350996274.0022

http://hdl.handle.net/10138/315028

https://doi.org/10.5040/9781350996274.0022

acceptedVersion

Downloaded from Helda, University of Helsinki institutional repository.

This is an electronic reprint of the original article.

This reprint may differ from the original in pagination and typographic detail.

Please cite the original version. 


\section{Bloomsbury Education and Childhood Studies Article Template}

Please write your article directly into this template.

\begin{tabular}{|l|l|}
\hline Section & Secondary Education \\
\hline Article topic & Management, leadership and governance \\
\hline Country & Finland \\
\hline Author 1 & Janne Varjo \\
\hline $\begin{array}{l}\text { Author 1 } \\
\text { affiliation }\end{array}$ & Janne Varjo is University Lecturer at the University of Helsinki, Finland \\
\hline Author 2 & \\
\hline $\begin{array}{l}\text { Author 2 } \\
\text { affiliation }\end{array}$ & $12 / 2018$ \\
\hline Date created & Number of words of the text of the article \\
\hline Length & \\
\hline
\end{tabular}

\section{Keywords [not included in total word count]}

- Lower secondary education, General upper secondary education, upper secondary vocational education and training, joint application system, Matriculation Examination, municipality

Glossary terms [not included in total word count]

- The Finnish Education Evaluation Centre: The Finnish Education Evaluation Centre is an independent agency responsible for the evaluation of education. It operates as a separate unit within the Finnish National Agency for Education. It carries out evaluations related to education including the operations of education providers, from early childhood education to higher education. (https://karvi.fi/en/fineec/)

- The Finnish National Agency for Education: The National Agency works under the auspices of the Ministry of Education and Culture. One of its main duties is to work on the national core curricula for pre-primary education, basic education, general upper secondary education, and the curricula for preparatory education for immigrants and morning and afternoon activities for school children (https://www.oph.fi/english/curricula_and_qualifications).

- Joint application system: The application to upper secondary schools, both general and vocational, takes place through the joint application system. The selection of students for upper secondary school is based on their grade point average in the basic education certificate. Entrance and aptitude tests may also be used, and students may be awarded points for hobbies and other relevant activities. (https://www.infopankki.fi/en/living-in-finland/education/joint-applicationand-entrance-exams).

- Matriculation Examination: A national examination generally taken at the end of the Finnish upper secondary school. Its purpose is to discover whether students have assimilated the knowledge and skills required by the curriculum for upper secondary school, and whether they have reached an adequate level of maturity in line with the goals of general upper secondary education. (https://www.ylioppilastutkinto.fi/en/).

- Municipality: An administrative division having corporate status and powers of self-government as granted by the national laws to which it is subordinate. In 2018, Finland consists of 311 municipalities. They are the main providers of basic education (Varjo \& Kalalahti 2018).

- Student welfare group: Pupils in lower secondary education as well as students in upper secondary education have the right to student welfare services. It consists of services as specified in the education provider's curriculum. These include the services of psychologists and 
school social workers as well as pupil and student healthcare services.

(https://minedu.fi/en/pupil-and-student-welfare).

Text of the article $[1000-1500$ words]

\section{Research on management, leadership and governance}

The Finnish nine year compulsory basic education consists six years of primary (ISCED 1) and three years of lower secondary education (ISCED 2). One of the key principles is that after basic education, provided along comprehensive and universalist principles, all young people should have equal opportunity to undertake high-quality upper secondary education and training. The same educational opportunities should be available to everybody irrespective of their ethnicity, migration background, age, gender, wealth, disability or place of residence.

After the nine years of basic education, the Finnish system diversifies into two non-compulsory branches and tracks students into general upper secondary schools and vocational upper secondary institutions (ISCED 3). This transition is a high stakes situation in the Finnish education system. (Varjo, Kalalahti \& Jahnukainen 2019.)

\section{Structure}

Lower secondary education (ISCED 2) in Finland refers to the last three years of basic, universal education in a nine-year comprehensive school system which is meant for children aged between seven and 16 years. Lower secondary education is provided mainly by the sub-ordinate bodies of the state, municipalities. Local education authorities make the decisions on the allocation of funding, local curricula and recruitment of personnel. The municipalities also have the autonomy to delegate decision-making power to the schools, if they see fit. (FNAE 2017.)

After compulsory lower secondary education school-leavers opt for general or vocational upper secondary education and training (ISCED 3), typically at the age of 15 or 16. The application to upper secondary schools, both general and vocational, takes place through the joint application system.

The selection of students for upper secondary education is based on their grade point average in the basic education certificate. Entrance and aptitude tests may also be used, and students may be awarded points for hobbies and other relevant activities. Both general and vocational upper secondary education and training usually take three years and give eligibility for higher education.

Upper secondary education is provided by different types of education providers: municipalities, joint municipal authorities, the state and the private education providers. Municipalities are the biggest group of education providers also at the upper secondary level. The Ministry of education and culture grants the license for providing education.

\section{Administration}

The Government and the Ministry of Education and Culture are responsible for preparing and implementing education policy. They make decisions on the common national objectives for lower and upper secondary education, on the division of time used for teaching lessons in various subjects and subject areas, and on the distribution of time used for guidance counselling. The Finnish National Agency for Education decides on the objectives and key contents, stated in the national core curriculum and the general goals of vocational education and training. 
Each municipality has a politically elected body that can be a local education board or other similar committee. Local education departments are responsible for planning, preparing and implementing education matters in line with the decisions made by the board. Municipals and other education providers make the decisions on the allocation of funding, local curricula and recruitment of personnel.

There is no statutory obligation for municipalities to provide general upper secondary education and vocational education and training, but they are obligated to assist in financing them. General upper secondary schools are mostly municipal institutions. Vocational institutions are maintained by the municipalities, joint municipal authorities (federations of municipalities), the state and private organizations.

Every secondary school has a principal who is responsible for its activities. If local education authorities so decide, municipal schools can have a board of directors that coordinates activities. Many such boards are also represented by the students' parents. Lower secondary schools may also have a student council, which is the voice of the students in school-related matters, and it includes representatives from each grade, who the students themselves have elected. In a similar vein, each institution providing general or vocational upper secondary education and training must have a student body composed of students, with the task of promoting student co-operation and schoolwork.

The institutional administration of education provided by the state and private organizations is governed by the Act on the Administration of State and Private Education (Law 634/1998), which stipulates that the responsibility for organization, development and administration of education rests with an institutional board, which consists of at least three members.

\section{Leadership}

In educational institutions at secondary level the management responsibility generally lies with the principals. Due to the local autonomy in the provision and administration of education, municipalities and private providers are free to organize their management as they see fit. In lower secondary and general upper secondary schools there is commonly also a vice-principal who shares the management duties. In vocational education and training there are often department heads who are responsible for the training in their department. Larger secondary schools have set up flexible team structures and leadership teams include representatives of both principals and teachers. Team responsibilities and membership of the leadership team are generally included in teachers' job descriptions on a fixed-term basis. (Taipale, 2012.) Other staff in lower and upper secondary education and training comprises guidance, health care, social welfare and special needs personnel, working jointly in student welfare groups.

In Finland, the selection procedure of principals and teachers for municipal schools is determined in the municipal standing order. All posts are advertised for public application. Superiors select their own subordinates in many municipalities, with the exception of the highest-ranking officials, who are selected by the municipal council or board of education. There are no common regulations for a consultation procedure, but teaching staff and representatives of parents are often consulted when defining a new principal's competencies or also while comparing applicants for the post. Principals are initially appointed to their posts for a six-month trial period on a fixed-term basis. (Taipale 2012.) Private education providers may decide which of their bodies is responsible for appointing new principals and teachers. 
Principals, appointed by local educational authorities, are required to have a teacher qualification (up to a master's degree), a certificate in educational administration and teaching experience. There is no national regulation regarding participation in training for principals, which is the responsibility of education providers. (OECD 2013.).

\section{Supervision}

Finland abandoned school inspections at basic education in the early 1990s, unlike the other Nordic countries (Simola et al. 2017). According to Basic Education Act (628/1998) education providers at the lower secondary level are responsible for evaluating the education and training that they provide and for participating in national or international evaluation work. Nevertheless, evaluation data about school operations and performance is collected regularly to support education policy decisionmaking. Comparative data on individual comprehensive schools is not made public. Education providers and schools use evaluation data in their development work. Schools have a self-evaluation obligation, while responsibility for external evaluations lays with education providers. (Taipale 2012; Kauko \& Varjo 2008.)

A nationally significant form of external evaluation and a measure of academic achievement is the common final examination at general upper secondary school, i.e. the Matriculation Examination, which is organized twice every year. At present, over half of the relevant age group participates in the matriculation examination, which can also be taken by vocational students. Universities and polytechnics take the grades of this final examination into account in their admission procedures instead of or alongside entrance examinations. School specific results are published every year by the media and they have a bearing on young people's general upper secondary school choices. (Taipale 2012.)

A key role in vocational education and training directed to adults at upper secondary level is played by the Qualification Committees, which are bodies appointed by the Finnish National Board of Education to implement competence-based qualifications. The Qualification Committees are responsible for organizing and supervising competence tests, monitoring the effectiveness of the competence-based qualifications system in their respective VET fields and, where necessary, making initiatives concerning its development. (NBE 2010.)

Moreover, Finnish Education Evaluation Centre's sample-based themed and system evaluations provide information on, for example, upper secondary school pedagogy or upper secondary school students' further education abilities.

\section{Challenges}

Age classes are decreasing in most parts of the country; because of this special attention has to be paid to the scale of the school network at all school levels. The competition for students between upper secondary educational institutions will increase unless educational institutions start cooperating more closely and, for example, rearrange their administration. (MoE 2007.)

The reform of vocational upper secondary education is one of the Prime Minister Juha Sipilä's Government's key project (Gov. 2015). The reform updates the entire vocational education and training. In the future, work life will require new kinds of competencies, while there are fewer financial resources available for education. Vocational education and training has to respond more swiftly to changes in work life and operating environment and to adapt to individual competence needs. Hence, it has to be competence-based and customer-oriented. 


\section{Further reading and online resources [not included in total word count]}

- Association of Finnish Local and Regional Authorities. https://www.localfinland.fi/ [accessed 23 November 2018]

- Finnish National Agency for Education. https://www.oph.fi/english [accessed 26 November 2018]

- MoE. (2007), Improving School Leadership, Finland. Country Background Report. Publications of the Ministry of Education 2007:14, Helsinki: Ministry of Education.

- Sahlberg, P. (2011), Finnish Lessons: What can the world learn from educational change in Finland? New York, NY: Teachers College Press.

- Simola, H., Kauko, J., Varjo, J., Kalalahti, M. and Sahlström, F. (2017), Dynamics in Education Politics - Understanding and explaining the Finnish case, London: Routledge.

\section{References [not included in total word count]}

Gov. (2015). Finland, a land of solutions: Strategic Programme of Prime Minister Juha Sipilä's Government. Government Publications 12/2015, Helsinki: Government of Finland.

Kauko, J. and Varjo, J. (2008), Age of Indicators - Changes in the Finnish Education Policy Agenda, European Educational Research Journal, 7, 219-231.

Law 634/1998. Act on the Administration of State and Private Education.

MoE. (2007), Improving School Leadership, Finland. Country Background Report. Publications of the Ministry of Education 2007:14, Helsinki: Ministry of Education.

NBE. (2010). Vocational education and training in Finland. Vocational competence, knowledge and skills for working life and further studies, Helsinki: National Board of Education.

NBE. (2013). Competence-based Qualification Guide. Publications 2013:22, Helsinki: National Board of Education.

OECD. (2013), Education Policy Overview: Finland, Paris: Organization for Economic Co-operation and Development.

Simola, H., Kauko, J., Varjo, J., Kalalahti, M. and Sahlström, F. (2017), Dynamics in Education Politics Understanding and explaining the Finnish case, London: Routledge.

Taipale, A. (2012), International survey on educational leadership: A survey on school leader's work and continuing education. Publications 2012:12, Helsinki: The Finnish National Agency for Education.

Varjo, J. and Kalalahti, M. (2018), 'The art of governing local education markets - municipalities and school choice in Finland', Education Inquiry, Print ahead https://doi.org/10.1080/20004508.2018.1514907 [accessed 22 November 2018].

Varjo, J., Kalalahti, M. \& Jahnukainen, M. (2019), 'Educational trajectories of immigrant-origin youth: Reasoning behind the choice for upper secondary education', Education Inquiry. (In print) 